\title{
Development of Set and Logic Learning Tools and Problem-Based
}

\author{
$1^{\text {st }}$ Pargaulan Siagian ${ }^{1}, 2^{\text {nd }}$ Waminton Rajagukguk ${ }^{2}, 3^{\text {rd }}$ Katrina Samosir $^{3}$ \\ \{pargaulansiagian19@gmail.com ${ }^{1}$ \} \\ Department of Mathematics, Faculty of Mathematics and Natural Sciences, Universitas Negeri \\ Medan, Indonesia ${ }^{1,2,3}$
}

\begin{abstract}
Pargaulan Siagian. "Development of Set Learning Tools and Problem-Based Logic" in odd semester lectures in 2021. This research is a learning device development research that aims to: (1) describe the development process and produce a valid, practical, and effective learning device set and logic based on problems; (2) to find out whether problem-based learning on Set and Logic learning can improve student lecture outcomes. The device was developed using the Thiagrajan development model. The trial of the development of this device was conducted on the Mathematics Education S1 Study program on Set and Logic learning. This research, has resulted in set and logic learning tools, in the form of: Set and Logic Textbooks, and 14 Valid, practical and effective Lecture Event Units (SAP).
\end{abstract}

Keywords: Development of learning tools, validity, practicality, and effectiveness.

\section{Introduction}

A set is a collection of objects that have certain and clear conditions. The collection is a list, a collection, a class. As for objects can be concrete objects or abstract objects. Objects that are members or set elements. The set is usually symbolized by capital letters, for example: I, D, O, L, A. While Logic is a field of knowledge in a philosophical environment that regularly studies the principles and rules of correct reasoning.

The set is an important part of the curriculum, this material is closely related to the previous material, namely the concept of numbers and subsequent concepts such as Algebra. The set is often a connecting bridge between one concept and another. Mathematical logic is an important component in mathematics.

Mathematical logic is a science that examines the value of truth from statements, as well as the validity of a mathematical argument built on statements in their premise and conclusion. With mathematical logic, it can understand the definition (concept) so that it can judge the correctness of the example and not the example of the defined element. Through mathematical logic, it will be able to understand the relationship between two concepts that exist in a theorem / evidence / law (mathematical principles). Compared to logic used in other sciences, mathematical logic has certain characteristics. Mathematical logic is deductive. Therefore, truth in mathematics is usually seen based on consistency.

As long as the conclusions obtained are based on what has been agreed as a mathematical truth (facts, concepts, principles, mathematical procedures), and using valid conclusions (ponen mode, tolens mode, and silogisma), then the conclusion is a mathematically correct 
conclusion. As long as the conclusions obtained are based on what has been agreed as a mathematical truth (facts, concepts, principles, mathematical procedures), and using valid conclusions (ponen mode, tolens mode, and silogisma), then the conclusion is a mathematically correct conclusion [1].

Understand the concepts of Mathematical Set and Logic, use each concept to solve problems and or draw valid conclusions and improve their reasoning and communication skills.

The modern logic outlined in this logic will not justify things that are neither logical nor their content. Modern logic is based on the breadth of concepts or so-called based on the set because every word, every term, and every statement basically reveals a set.

It is this set that is the basis of modern logic, and the set is defined "a set of things that have certain characteristics of the same". On the basis of the set, all elements of reasoning in the logic of proof using the set diagram is a formal proof if expressed with a valid and precise set diagram then it is valid and precise also the reasoning. Likewise, if the proof is correct, then the reasoning is correct so that it is said that the truth of the form is in accordance with the content.

\section{Theory}

\subsection{University Plan}

In accordance with Unimed Strategic Plan launched since 2008: The increase in resources will also pay attention to the needs of existing study program development as well as national needs related to education and research services. Education research policy based on real needs in schools is carried out to enrich educational materials in the form of innovations in learning. The development of effective and efficient learning resources and education systems will be pursued by involving academicians working with others concerned.

Improving the quality of learning will lead to improving the quality of human resources and the well-being of people's lives. As the only state LPTK in North Sumatra, Unimed should be a consulting center for problem solving in the field of education. Unimed lecturers will be encouraged to produce publications either in the form of books or writings published in the National / International Journal in an effort to improve the quality of education and the role and development of science. Improving the quality of learning will lead to improving the quality of human resources and the well-being of people's lives. As the only state LPTK in North Sumatra, Unimed should be a consulting center for problem solving in the field of education. Unimed lecturers will be encouraged to produce publications either in the form of books or writings published in the National / International Journal in an effort to improve the quality of education and the role and development of science.

Learning activities that take place on campus are formal, deliberate, planned, with the help of teachers and other educators. The learning process in the classroom is inseparable from the role of a teacher who is a professional educator. The teacher's professional skills are part of the teacher's competence. It is written in Law No. 14 of 2004 on Teachers and Lecturers states that the competence of teachers, and lecturers include pedagogic competencies, personality competencies, social competencies, professional competencies obtained through professional education. 
With the demands of professional competence, every lecturer in the education unit is obliged to develop a complete and systematic learning tool so that the learning takes place interactively, inspiring, fun, challenging and motivating students to actively participate, as well as provide sufficient space for creativity and independence initiatives in accordance with the talents, interests, and physical and psychological development of students. Lecturers are required to be able to create and develop the lecture devices that will be implemented.

Learning tools are tools used in the learning process [2]. Some of the necessary learning tools include: Lecture Event Unit (SAP), Syllabus of lecture materials, Student Worksheet (LKPD), textbooks and problem solving skills test in set and logic. Device preparation is an early stage in learning. Therefore, the quality of the lecture devices used also determines the quality of the courses programmed. To produce good quality lecture devices, the lecture devices must be prepared based on scientific, valid, practical, effective, systematic, and mature rules.

\subsection{Problem Solving Ability}

Problem solving is an action to solve a problem or process that uses the power and benefits of mathematics in solving problems, which is also a method of finding solutions through the stages of problem solving. It can also be said that problem solving as an effort to find a way out of a difficulty.

Problems in mathematics learning are questions that must be answered or responded to. But not all automated questions will be a problem. A question will be a problem only if it indicates a challenge that cannot be solved by a routine procedure that is already known by the student.

Problems in mathematics learning are questions that must be answered or responded to. But not all automated questions will be a problem. A question will be a problem only if it indicates a challenge that cannot be solved by a routine procedure that is already known by the student.

Problem solving is the process of applying previously gained knowledge into new unknown situations or thought processes to determine what to do when we do not know what to do [3].

Problem solving skills are strategic skills or competencies that students demonstrate in understanding, choosing approaches and solving strategies and solving models to solve problems [4].

Indicators that demonstrate problem solving skills include: Identifying known elements, being asked, and adequacy of necessary elements, Formulating mathematical problems or putting together mathematical models, Applying strategies to solve various problems (similar and new problems) in or outside mathematics, Explaining or interpreting results according to original problems, and Using mathematics meaningfully [5].

Activities covered in problem solving activities include: (1) identifying known, questionable, and adequacy elements as needed, (2) formulating daily and metematic situation problems; apply strategies to solve various problems (similar and new problems) in or out of mathematics, (3) explain / interpret the results according to the original problem, (4) develop a mathematical model and solve it for real problems and use mathematics meaningfully.

Strategies for solving a math problem there are several strategies that can be used depending on the problem to be solved. However, there is a common problem-solving strategy that George Polya suggests. To solve a problem there are four steps that can be done, namely [6]: 
1. Understanding the problem Activities that can be done in this step are what (data) is known, what is unknown (asked), whether enough information, what conditions (conditions) must be met, re- stating the original problem in a more operational form (can be solved).

2. Planning a solution Activities that can be done in this step is to try to find or remember the problems that have been solved that have similarities to the problem to be solved, look for patterns or rules, draw up a settlement procedure (create a conjecture). Planning a solution Activities that can be done in this step is to try to find or remember the problems that have been solved that have similarities to the problem to be solved, look for patterns or rules, draw up a settlement procedure (create a conjecture).

3. Resolve the problem according to the activity plan that can be done in this step is to run the procedure that has been created in the previous step to get the solution.

4. Re-examine the procedures and results of completion Activities that can be done in this step is to analyze and evaluate whether the procedures applied and the results obtained are correct or whether the procedure can be generalized.

Thus the essence of learning to solve problems, so that students are used to working on problems that not only rely on good memory, but students are expected to relate to real situations that have been experienced or that have been thought of.

\subsection{Problem-Based Learning (PBL)}

PBL is diametrically different from ordinary learning. If ordinary learning culminates in problem solving after the presentation of mathematical objects, then PBL starts from a problem to build mathematical knowledge and skills in a relevant context.

In addition, Moffit in Berns and Erickson in the Department of National Education, stated: Problem-based learning is an approach that involves students in problem-solving investigations, integrating skills and concepts from a variety of content areas. PBL is a learning approach that uses real-world problems as a context for students to learn about critical and creative thinking, problem solving skills, and to acquire essential knowledge and concepts from the subject matter [7].

PBL approach has three main things, namely students solve problems according to their ability, problems are not ill-structured means the lack of information needed and contains unresolved issues become complex through incuture and investigation, requiring reasons to be solved, if possible can be solved better than a way.

The stages of problem-based learning model consists of five main stages [8] [9]: Starting from the lecturer introducing to students about the problem situation. Organizing students to learn (assisting students in defining problems). Guiding the investigation conducted by students on the situation of the problem presented both individually and in groups. Until finally the teacher helps students in developing. Lecturers help students present analysis of the work that has been done by students.

\subsection{Problem Based Learning Syntax}

From the stages of problem based model above, the steps of learning model with Problem Based Learning approach [9] can be seen in the following table: 
Table 1. Problem Based Learning Syntax.

\begin{tabular}{|c|c|c|}
\hline Phase & Indicator & Lecturer Activity \\
\hline 1 & $\begin{array}{l}\text { Student orientation on } \\
\text { theissue }\end{array}$ & $\begin{array}{l}\text { Lecturer explains learning objectives, explain logistics } \\
\text { needed,motivates students to engage in problem solving } \\
\text { activities }\end{array}$ \\
\hline 2 & $\begin{array}{l}\text { Organizing students to } \\
\text { study organizing } \\
\text { students to study }\end{array}$ & $\begin{array}{l}\text { Lecturers help students define and organize learning } \\
\text { tasksrelated to the problem }\end{array}$ \\
\hline 3 & $\begin{array}{l}\text { Guiding individual } \\
\text { and group } \\
\text { investigations }\end{array}$ & $\begin{array}{l}\text { Lecturer encourage students to gather appropriate } \\
\text { information,carry out observation carry out observation, to } \\
\text { solve problems. }\end{array}$ \\
\hline 4 & $\begin{array}{l}\text { Develop and present } \\
\text { thework }\end{array}$ & $\begin{array}{l}\text { Lecturer assist students in planning and preparing } \\
\text { appropriate work, such as: reports, and help them to share } \\
\text { assignments withtheir friends }\end{array}$ \\
\hline 5 & $\begin{array}{l}\text { Analyze and evaluate } \\
\text { the troubleshouting } \\
\text { process }\end{array}$ & $\begin{array}{l}\text { Lecturer help students to reflect or evaluate their } \\
\text { investigationsto reflect or evaluate their investigations and the } \\
\text { processes they use }\end{array}$ \\
\hline
\end{tabular}

\section{Method}

This research is research and development (developmental research) using the model of development of 4D model Thiagrajan. Research and development method is a research method used to produce a particular product, and test the effectiveness of the product [10].

The subjects in this study were students of Mathematics Education FMIPA Unimed. While the object is a set of learning tools and logic developed in this study. The subjects in this study were students of Mathematics Education FMIPA Unimed. While the object is a set of learning tools and logic developed in this study.

The type of development that will be carried out is the 4-D model presented by Thiagarajan, Semmel, and Semmel which is modified into four stages, namely: the first stage of definition, the second stage of the design, the third stage of development and the fourth stage of deployment.

\subsection{Research Methods and Stages}

Define Stage. The purpose of the definition level here is to establish and define the needs of the lesson by analyzing the objectives and limitations of the material developed by the teaching material. In this stage includes 5 main steps, namely (a) front end analysis; (b) student analysis; (c) task analysis; (d) concept analysis; and (e) formulation of learning objectives.

Design Stage. The design stage aims to design learning tools. Four steps that must be done at this stage, namely: (a) the preparation of standard benchmark reference test (constructing criterion-referenced test), (b) media selection (media selection) that corresponds to the 
characteristics of the material and learning objectives, (c) selection of formats (format selection), namely reviewing the formats of existing teaching materials and establishing the format of teaching materials to be developed, (d) making the initial design according to the selected format.

Development Stage. The development stage is the stage to produce development products carried out through two steps, namely: (1) expert appraisal followed by revision, (2) developmental testing. The purpose of this stage of development is to produce the final form of instruments and teaching materials after going through revisions based on expert input and test result data.

Disseminate Stage. The dissemination process is a final stage of development. The dissemination stage is done to promote the development product in order to be accepted by the user, whether an individual, a group, or a system. Manufacturers and distributors must be selective and work together to package the material in the right form. Dissemination can be done in other classes with the aim of knowing the effectiveness of using the device in the learning process. Dissemination can be done through a process of dissemination to related learning practitioners in a particular forum.

The instruments used in this development research are (1) validation sheets; (2) assessment sheet of experts and practitioners on the practicality and effectiveness of teaching materials; (3) observation sheet; (4) questionnaire response of students and lecturers; and (5) test learning outcomesThe instruments used in this development research are (1) validation sheets; (2) assessment sheet of experts and practitioners on the practicality and effectiveness of teaching materials; (3) observation sheet; (4) questionnaire response of students and lecturers; and (5) test learning outcomes.

This research was conducted in the fourth semester of Mathematics Education Program FMIPA Unimed as many as 30 students. The devices compiled are: Textbooks, Lecture Event Units (SAP). To obtain an effective Prototype Device implemented on the 30 students

The data obtained is analyzed and directed to answer the question of whether the instruments and teaching materials based on the problem-based learning approach developed have met the criteria of validity, practicality, and effectiveness. Data analysis in the development of teaching materials is used descriptive statistical analysis techniques. The data obtained is analyzed and directed to answer the question of whether the instruments and teaching materials based on the problem-based learning approach developed have met the criteria of validity, practicality, and effectiveness. Data analysis in the development of teaching materials is used descriptive statistical analysis techniques.

\subsection{Teaching Material Development Criteria}

A high quality material referred to three quality criteria namely validity, practicality and effectiveness [11]. A material is said to be of quality if it meets: validity, practicality, and effectiveness.

Validity. Valid means "as and should be, valid or valid". Validity refers to the extent that the design of the intervention includes "state of the art knowledge" (content validity) and the various components of the intervention are consistently linked to each other (construct validity) [11]. It means that the validity aspect of the material is seen from whether the various 
components of the material are consistently related to each other, so that the teaching materials based on problem-based learning approach are said to be valid if the teaching materials are designed based on a strong theoretical rationale and the various components in the teaching materials are consistent internally.

Practicality. Practical, means easy to use in practice. Assessment using problem-based learning is said to be practical if the results show that the student who used the assessment considers the assessment to meet the needs, expectations, and boundaries. Authentic assessment indicators developed practically, the response of lecturers, and students on the assessment is good.

Effectiveness. Effectiveness in development research, "effectiveness refer to the extent that the experiences and outcomes with the intervention are consistent with the intended aims" [12]. While, the effective criteria of learning when fulfilling [13], namely: (1) the achievement of learning outcomes is at least $80 \%$ classical completion; (2) student activities meet the established time tolerance criteria; (3) more than $50 \%$ of students respond positively to the learning tools developed; and (4) the ability of lecturers to manage category learning well.

\section{Results and Discussion}

\subsection{Lecture Device Validation Results in SAP 1-SAP 15}

After this research was conducted it turned out that the summary of the validation results of learning devices developed before the mid-test was carried out. The devices in question are set and logical textbooks consisting of 14 chapters, are as follows:

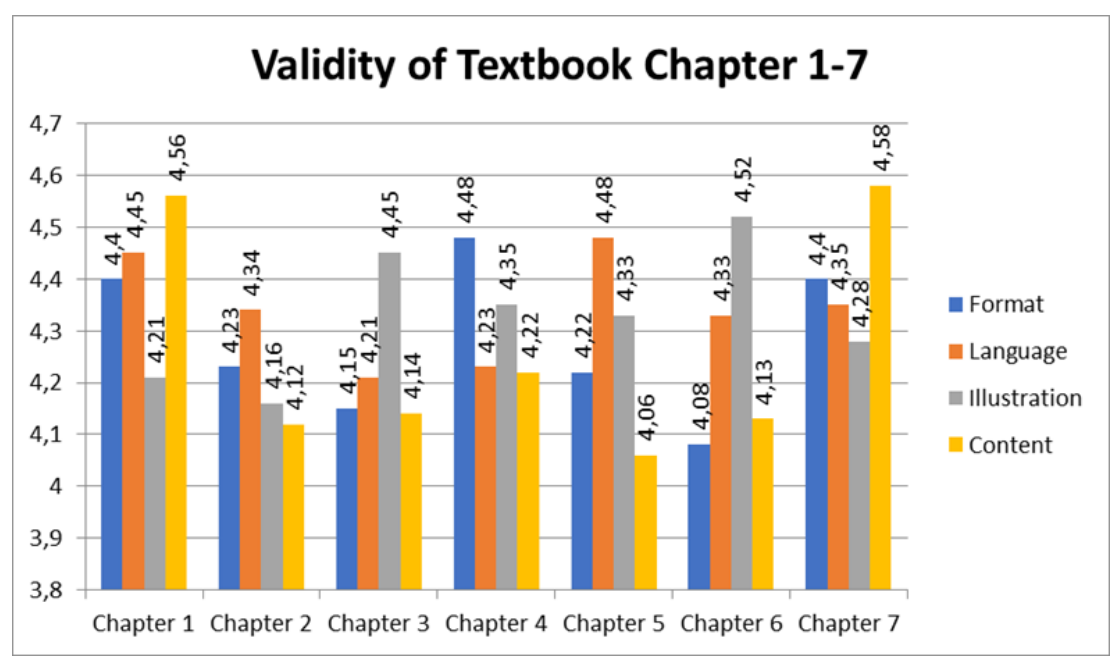

Fig. 1. Validity Chapter 1 - Chapter 7 Textbooks Created. 


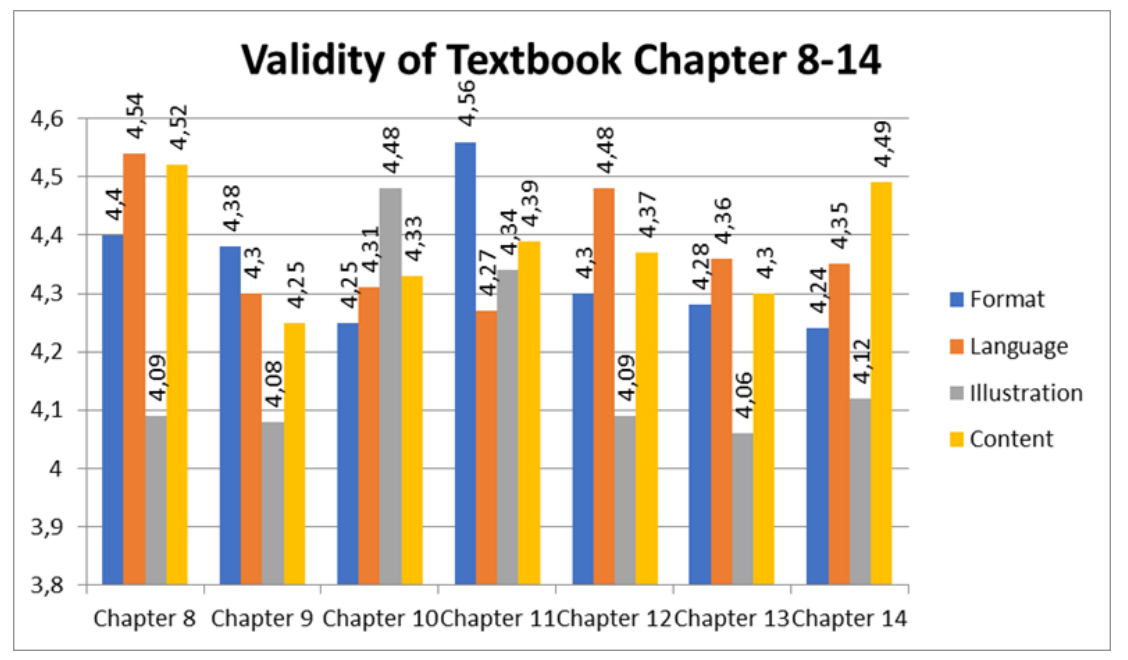

Fig. 2. Validity Chapter 8 - Chapter 14 Textbooks Created.

\subsection{Student Response Results to the Lecture Process}

Student response result to lectures conducted through SAP 1-SAP 7 before Mid Test is conducted. The students' response can be seen through the following figure:

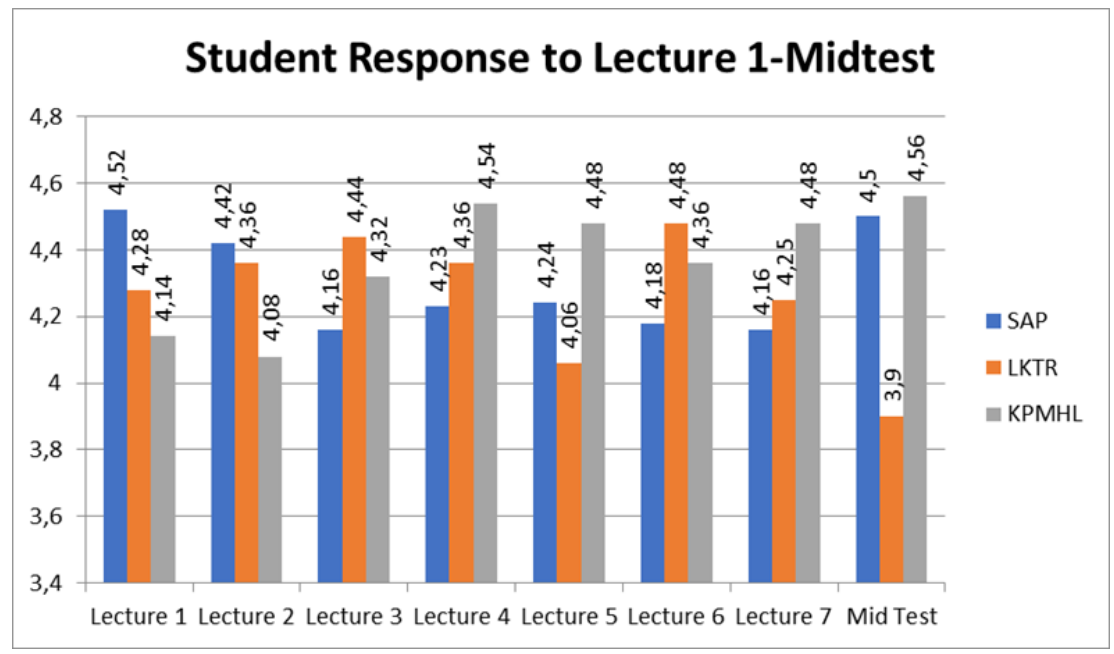

Fig. 3. Student response participants Set and Logic.

Furthermore, students can see the response to lectures conducted through SAP 9-SAP 15 after mid test. The students' response can be seen through the following figure: 


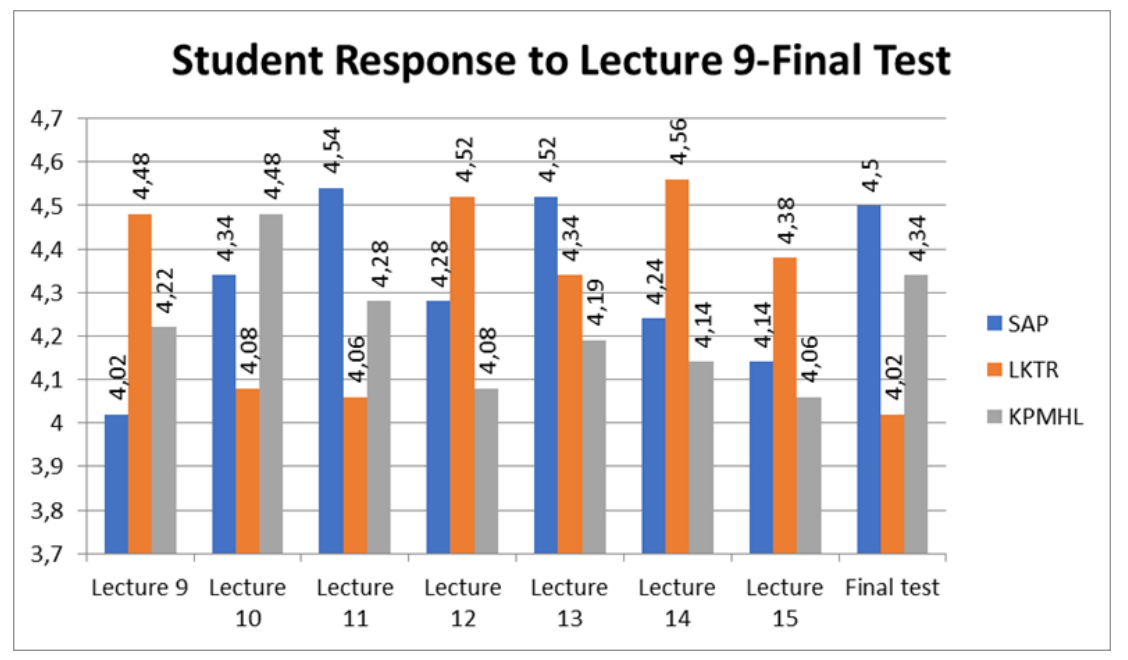

Fig. 4. Student response participants. Set and Logic.

\subsection{Results of Effectiveness of SAP 1-SAP 15 Lecture Device}

Effectiveness of SAP 1-SAP 7 Lecture Device

After this research was conducted it turned out that the summary of the results of the effectiveness of learning devices developed before the mid test was carried out. The tools in question are Routine Task Worksheets and Set and Logic Problem Solving Skills as follows: Completion of Lecture process in SAP 1-SAP 8 (before mid test) programmed trial 1 and trial 2 views student absorption:

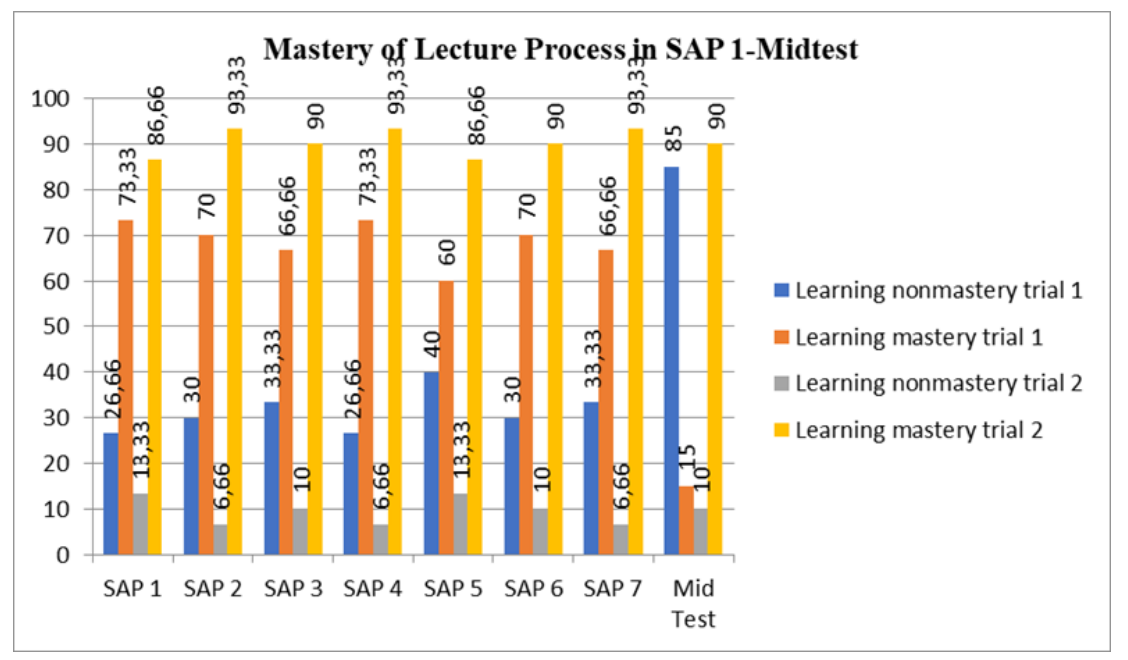

Fig. 5. Completion of KPMHL Implementation Program in SAP 9 - SAP 15 Students of participants Set and Logic. 
Completion of lecture process in SAP 9-SAP 16 (after mid test) programmed trial 1 and trial 2 seen student absorption:

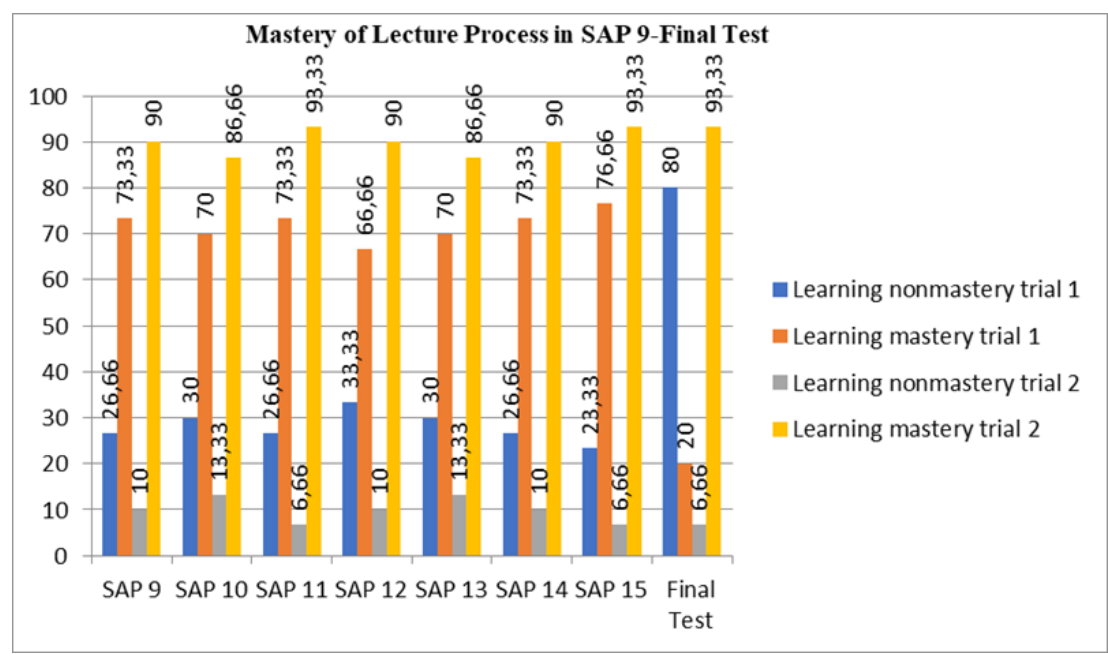

Fig. 6. Completion of KPMHL Implementation Program in SAP 9 - SAP 15 Students of participants Set and Logic.

Improvement of lecture program results through sap 1 to SAP 7 implementation before mid test that has been implemented, as follows:

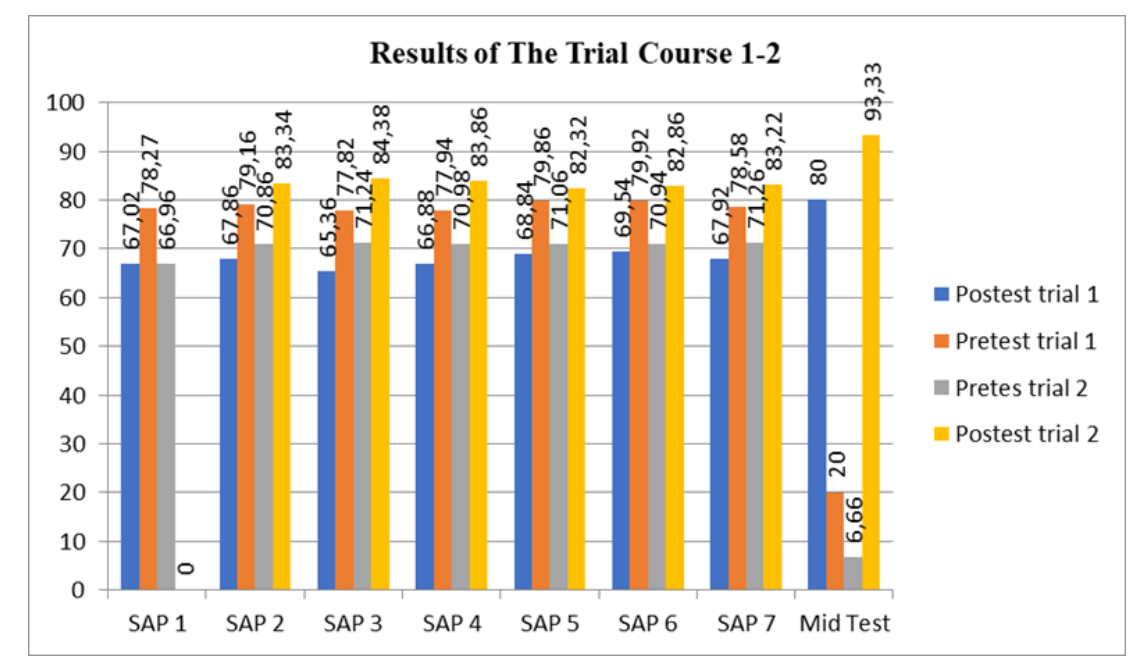

Fig. 7. Improvement of KPMHL Results in SAP 1 - SAP 7 students of participants. Set and Logic.

Improvement of lecture program results through the implementation of SAP 9 to SAP 15 and before the final test that has been implemented, as follows: 


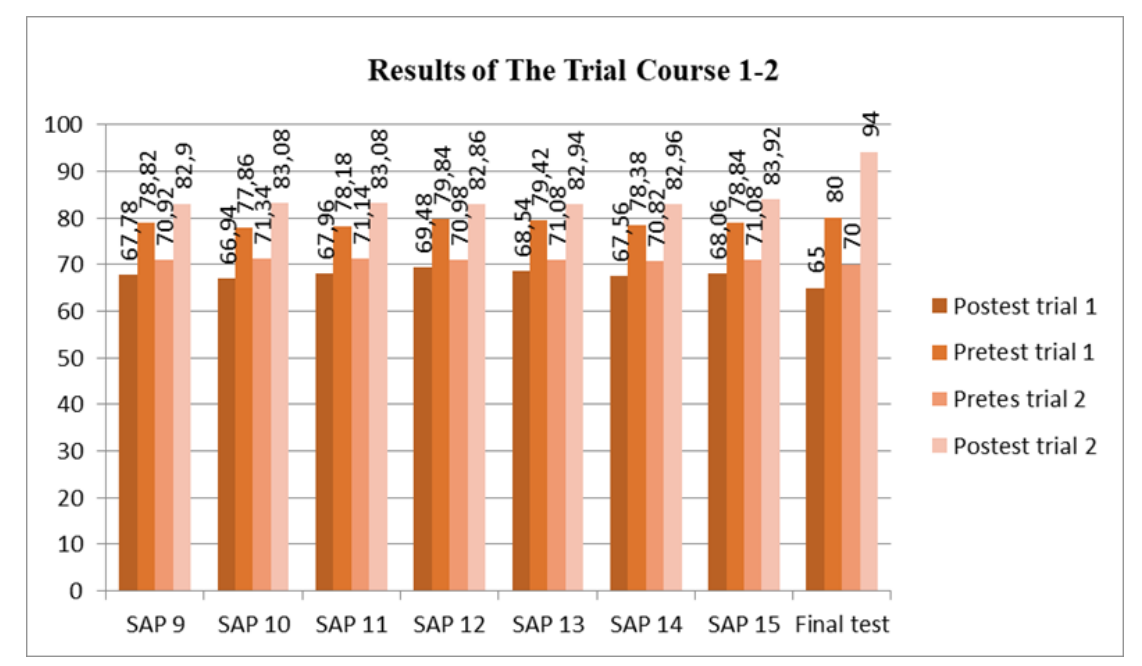

Fig. 8. Improvement of KPMHL Results in SAP 9 - SAP 15 students of participants Set and Logic.

\section{Conclusion}

Based on the description in the previous chapter, it can be concluded that the following: Set and Logic-based learning tools, each Textbook, Lecture Event Unit, and Routine Task Worksheet have fulfilled validity, practicality, and effectiveness.

\section{References}

[1] Guru Pembelajar \& Tenaga Kependidikan. Teori Belajar, Himpunan, dan Logika Matematika Modul Matematika. Jakarta: Direktorat Jenderal Guru \& Tenaga Kependidikan Kementerian Pendidikan Kebudayaan; 2016.

[2] Trianto. Mendesain Model Pembelajaran Inovatif-Progresif. Surabaya: Kencana Prenada Media Group; 2011.

[3] Siagian P. Prototype Teaching Mathematics in Improving Critical Thinking Ability of Senior High School Students. Int J Innovation in Sci Math. 2017; 5(2):57-61.

[4] Sinaga B. Pengembangan Model Pembelajaran Matematika Berdasarkan Masalah Berbasis Budaya Batak (PBMB3). Dissertation Not published. Surabaya: UNESIA; 2007.

[5] Sumarmo, et al. Suatu Alternatif Pengajaran untuk Meningkatkan Kemampuan Pemecahan Masalah Matematika pada Guru dan Siswa SMP. Bandung: Not published; 2014.

[6] Ruseffendi ET. Pengajaran Matematika Modern dan Masa Kini. Bandung: Tarsito; 1991.

[7] Depdiknas. Manajemen Pendidikan Mutu Berbasis Sekolah. Jakarta: Direktorat Jendral Pendidikan Dasar dan Menengah; 2002.

[8] Ismail. Pembelajaran Berdasarkan Masalah (Problem-Based Instrution). In TOT training Contextual learning. Surabaya; 2002.

[9] Ibrahim M, Nur M. Pengajaran Berdasarkan Masalah. Pusat Sains dan Matematika Sekolah. Program Pascasarjana UNESA: University Press; 2000.

[10] Sugiyono. Quantitative, Qualitative and R\&D Research Methodology. Bandung: Alphabeta; 2015

[11] Nieveen N. An Introduction to Education Design Research. China: The east China Normal University; 2007. 
[12] Akker Jvd. Principles and Methods of Development Research. In Plomp, T; Nieveen, N; Gustafson, K; Branch, R.M; dan van den Akker, J (eds). Design Approaches and Tools in Education and Training. London: Kluwer Academic Publisher; 1999.

[13] Herman. Pengembangan Perangkat Pembelajaran Model Pengajaran Langsung untuk Mengajarkan Materi Kesetimbangan Benda Tegar. Jurnal Sainsdan Pendidikan Fisika. 2012; 8(1):1-11. 